\title{
PENERAPAN PEMBELAJARAN LEARNING CYCLE 5E UNTUK MENINGKATKAN KEMAMPUAN KOGNITIF DAN AKTIVITAS BELAJAR SISWA KELAS VII
}

\author{
Maria Fidivanti ${ }^{1}$, Melkyanus Kaleka ${ }^{2}$, Yasinta Embu Ika ${ }^{3}$ \\ Fakultas Keguruan dan Ilmu Pendidikan Universitas Flores \\ Program Studi Pendidikan Fisika \\ email: fidivanti@gmail.com
}

\begin{abstract}
ABSTRAK
Penelitian ini adalah penelitian tindakan kelas. Tujuan penelitian ini adalah untuk meningkatkan kemampuan kognitif dan aktivitas belajar siswa melalui model pembelajaran learning cycle 5E. Subjek penelitian ini adalah siswa kelas VIIA Sekolah Menengah Pertama Swasta Kristen Ende tahun pelajaran 2018/2019. Pelaksanaan pembelajaran dilakukan dalam 2 siklus, yaitu setiap siklus terdiri dari 4 tahapan yang terdiri dari; perencanaan, pelaksanaan, observasi dan refleksi, dengan menggunakan prosedur penelitian yang dikembangkan oleh Kemmis dan Mc. Taggart. Instrumen pengumpulan data terdiri dari lembar observasi dan angket. Taknik analisis data menggunakan analisis deskriptif. Kesimpulan akhir dari penelitian ini adalah; (1) Pembelajaran learning cycle 5E dapat meningkatkan kemampuan kognitif siswa, yaitu jumlah siswa yang tuntas pada siklus I sebanyak 11 siswa (37\%) dan siklus II meningkat sebesar 30 siswa (100\%). (2) Pembelajaran learning cycle 5E dapat meningkatkan aktivitas belajar siswa, yaitu jumlah siswa yang tuntas pada siklus I sebanyak 13 siswa (43\%) dan meningkat pada siklus II sebanyak 30 siswa (100\%).
\end{abstract}

Kata Kunci: Learning Cycle 5E, Kognitif, Aktivitas Belajar, Penelitian Tindakan Kelas

\begin{abstract}
This research is classroom action research. The purpose of this study is to improve cognitive abilities and student learning activities through the learning cycle learning model 5E. The subjects of this study were students of class VIIA Ende Christian Private Middle School academic year 2018/2019. The learning process is carried out in 2 cycles, namely each cycle consisting of 4 stages consisting of; planning, implementation, observation and reflection, using research procedures developed by Kemmis and Mc. Taggart. Data collection instruments consisted of observation sheets and questionnaires. Data analysis techniques used descriptive analysis. The final conclusions of this study are; (1) Learning cycle 5E can improve students' cognitive abilities, namely the number of students completing in cycle I by 11 students (37\%) and cycle II increasing by 30 students (100\%). (2) Learning cycle 5E can increase student learning activities, namely the number of students who finished in cycle I by 13 students (43\%) and increased in cycle II by 30 students (100\%).
\end{abstract}

Keywords: 5E Learning Cycle, Cognitive, Learning Activities, Classroom Action Research 


\section{PENDAHULUAN}

Ilmu Pengetahuan Alam adalah salah satu mata pelajaran yang dipelajari pada Sekolah Menengah Pertama. Berbicara tentang IPA tidak semata-mata membahas kumpulan fakta, konsep, prinsip dan hukum yang dihafal, melainkan bagaimana menerapkan proses pembelajaran. Piaget (dalam Sugiantara, et al, 2012) dikatakan belajar akan menjadi efektif bila kegiatan belajar sesuai dengan tingkat perkembangan intelektual siswa dan tidak ada belajar tanpa perbuatan. Karena itu, mata pelajaran IPA tidak dapat diberikan dengan hanya ceramah saja, tetapi harus didasarkan pada pengalaman dimana siswa terlibat langsung secara aktif dalam kegiatan kongkret untuk memperoleh informasi, dan diharapkan kepada siswa untuk dapat membangun sendiri pengetahuannya.

Berdasarkan hasil wawancara dengan salah satu guru mata pelajaran IPA bahwa nilai rata-rata ujian nasional untuk tiga tahun terakhir masih sangat rendah. Hal ini dapat dilihat dari nilai rata-rata UN pada tabel berikut:

Tabel 1. Nilai Rata-Rata UN SMP Swasta Kristen Ende Tiga Tahun Terakhir
\begin{tabular}{|l|c|c|c|c|}
\hline \multirow{3}{*}{ Mata Pelajaran } & \multicolumn{3}{|c|}{ Tahun Ajaran } & Rata-Rata Per \\
& 2016 & 2017 & 2018 & Tahun \\
\hline Bahasa Indonesia & 60,0 & 54,31 & 62,46 & 58,93 \\
\hline Bahasa Inggris & 34,68 & 37,96 & 38,63 & 37.09 \\
\hline Matematika & 25,90 & 32,22 & 31,35 & 29,83 \\
\hline IPA & 40,85 & 38,0 & 41,88 & 40,24 \\
\hline
\end{tabular}

Selain itu, dari hasil pengamatan selama melakukan Praktik Pengalaman Lapangan (PPL) di SMP Swasta Kristen Ende selama kurang lebih tiga bulan, model pembelajaran yang sering digunakan dalam pembelajaran IPA adalah model discovery learning dengan metode ceramah, diskusi, yang pada intinya masih didominasi oleh guru. Metode yang digunakan cukup efektif, tetapi tidak semua siswa aktif dan kreatif di dalam pembelajaran. Terlihat dari nilai hasil ulangan pada kompetensi dasar 3.2 yang diikuti oleh 30 siswa dengan standar kriteria ketuntasan minimal (KKM) untuk mata pelajaran IPA di SMP Swasta Kristen Ende yaitu 70. Sementara hasil yang diperoleh untuk rata-rata ulangan 51,56\%, dengan lima orang mencapai KKM dan selebihnya masih jauh dibawah KKM.

Hal ini menunjukkan bahwa kemampuan kognitif siswa masih rendah. Kemampuan kognitif siswa yang berbeda berpengaruh terhadap hasil belajar siswa. Menurut Sudjana (dalam Sugiantara , et al, 2012) hasil belajar yaitu kemampuan yang dimiliki siswa setelah menerima pengalaman dalam kegiatan belajarnya. Dalam proses pembelajaran di kelas juga ditemukan beberapa masalah, diantaranya cara belajar dan kebiasaan belajar. Cara belajar siswa masih sangat keliru; misalnya membaca materi dalam waktu yang singkat pada saat menjelang ujian harian, motivasi siswa dan rasa ingin tahunya rendah. Adapun kebiasaan belajar siswa adalah pada saat guru menjelaskan materi siswa tidak mendengarkan dan memperhatikan dengan baik selama proses pembelajaran berlangsung, ada siswa yang bercanda dengan teman, ijin keluar, mengantuk, dan tidur. Hal ini menunjukkan bahwa aktivitas belajar siswa masih kurang. Oleh karena itu perlu diterapkan model pembelajaran 
yang inovatif dan kreatif, sehingga dapat meningkatkan kemampuan kognitif dan aktivitas belajar siswa serta pembelajaran menjadi lebih menantang dan menarik. Adapun salah satu model pembelajaran inovatif tersebut adalah Model Pembelajaran Learning Cycle 5E.

Model pembelajaran learning cycle $5 E$ merupakan suatu model pembelajaran yang menjadikan siswa sebagai tolak ukurnya. Siklus belajar 5E (learning cycle 5E) atau yang disebut LC 5E merupakan rangkaian tahap-tahap kegiatan (fase) yang diorganisasi sedemikian rupa sehingga siswa dapat menguasai kompetensi-kompetensi yang harus dicapai dalam pembelajaran dengan jalan berperanan aktif (Ngalimun dalam Lestari, et al, 2015). Model learning cycle $5 E$ adalah model pembelajaran yang berpusat pada siswa (student centered) yang terdiri dari tahap-tahap kegiatan yaitu; engagement, exploration, explaination, elaboration dan evaluation (Suastra dalam Sugiantara, et al, 2012). Menurut Wena (Handayani G.A., et al, 2014) model pembelajaran learning cycle adalah model pembelajaran dengan menggunakan pendekatan konstruktivis. Model pembelajaran ini sangat membantu siswa untuk lebih kreatif dan aktif daripada guru. Sesuai dengan tujuan pembelajaran yang ditetapkan pada Kurikulum 2013.

Dapat disimpulkan bahwa model pembelajaran learning cycle merupakan model pembelajaran yang dapat membantu siswa untuk membangun pengetahuan yang baru dengan membuat perubahan secara konseptual melalui interaksi dengan lingkungan dan dunia nyata agar siswa terlibat secara langsung saat proses pembelajaran. Melalui penerapan model ini diharapkan dapat membantu siswa lebih aktif dan kreatif dalam proses pembelajaran.

Model ini dikembangkan untuk menciptakan aktivitas pembelajaran yang efisien dan efektif dalam rangka meningkatkan kemampuan kognitif siswa. Dengan menggunakan model ini diharapkan mampu mengembangkan kemampuan yang dimiliki siswa dalam berbagai kegiatan belajar untuk berkreatif. Dalam hal ini, interaksi antara guru dan siswa harus sejalan dimana guru berperan sebagai pembimbing atau pendidik, sedangkan siswa berperan sebagai anak didik atau yang dibimbing (Mustiqon, 2012). Selain itu, guru sebagai pembimbing juga dituntut untuk membuat dan menggunakan pendekatan, metode, model-model pembelajaran yang disesuaikan dengan karakter siswa yang diajarnya, sehingga tujuan pembelajaran yang ditetapkan dapat tercapai setelah akhir pembelajaran (Sukir dalam Sugiantara, et al, 2012). Keberhasilan suatu pembelajaran tergantung dari partisipasi aktif dari siswa dalam mengikuti dan menghargai proses pembelajaran itu sendiri. Semakin aktif siswa mengikuti dan mengambil bagian dalam pembelajaran, maka tingkat keberhasilan pembelajaran juga semakin tinggi. Kemampuan kognitif dan aktivitas belajar siswa sangat ditentukan dalam proses pembelajaran tersebut.

Sesuai dengan namanya, model pembelajaran learning cycle ini memiliki lima tahapan (fase) dimana disetiap fasenya dimulai dengan huruf E. Adapun langkah-langkah model pembelajaran learning cycle $5 E$ ini, yaitu sebagai berikut:

1. Engagement (engage/keterlibatan)

Guru berusaha membangkitkan minat dan keingintahuan siswa tentang topik yang diajarkan. Pada tahap ini, guru akan menguji kemampuan awal siswa dengan memberikan pertanyaaan motivasi, memberikan gambaran tentang materi yang diajarkan, dan demonstrasi untuk mengembangkan rasa keingintahuan siswa. Dengan demikian, siswa memberikan tanggapan/jawaban. Hal ini, dapat dijadikan guru sebagai bahan untuk mengetahui tingkat kemampuan kognitif siswa siswa. 
2. Exploration (eksplore/penjelajahan)

Siswa diberi kesempatan untuk bekerja dalam kelompok-kelompok kecil tanpa pengajaran langsung dari guru. Dalam kelompok, siswa diminta untuk melakukan kegiatan laboratorium (praktikum) dengan cara mengamati (observasi), menyelidiki, membuat hipotesis serta melakukan percobaan, dan mengumpulkan data hasil percobaan untuk memecahkan masalah yang diberikan guru. Dalam fase ini, memberikan pengalaman yang nyata bagi siswa.

3. Explanation (eksplain/menjelaskan)

Guru dituntut mendorong peserta didik untuk menjelaskan suatu konsep dengan hasil pemikiran sendiri, meminta bukti dan klarifikasi atas penjelasan siswa, dan saling mendengarkan secara kritis penjelasan antar kelompok. Dengan begitu, siswa diharapkan untuk mampu membuat kesimpulan dan menjelaskan materi pelajaran yang dibahas. Tugas guru hanya sebagai fasilitator dan juga dapat memberikan solusi dalam diskusi tersebut ketika mereka butuh bantuan.

\section{Elaboration (elaborate/elaborasi)}

Siswa menerapkan konsep dan keterampilan yang telah diperoleh sebelumnya kedalam situasi baru atau konteks yang berbeda. Fase ini, mendorong siswa untuk dapat menerapkan materi yang telah diperoleh sebelumnya berdasarkan kegiatan yeng dilakukan ke dalam situasi yang baru. Dengan begitu, siswa dapat menggunakan konsep berbeda dalam situasi yang baru untuk dipelajari karena masalah baru memiliki penyelesaian yang samadengan yang materi sebelumnya. Hal ini dilakukan untuk siswa dalam memperkaya akan kemampuan yang mereka miliki sesuai dengan konsep yang dipelajari.

5. Evaluation (evaluate/menilai)

Guru dapat menilai pengetahuan atau pemahaman siswa dalam menerapkan konsep baru serta dapat mengamati proses pembelajaran yang telah berlangsung. Selain itu, siswa dapat menilai kemampuan mereka sendiri dengan mempelajari, mengerjakan ulang soal-soal yang diberikan guru serta mencari jawaban ynag menggunakan observasi dan penjelasan yang diperoleh sebelumnya. Fase ini, berpusat pada kemampuan yang dimiliki siswa dengan materi pelajarn yang mereka peroleh selama kegiatan pembelajaran.

Seperti yang dikatakan oleh Lorsbach (Yuliati, 2015) bahwa pada model pembelajaran learning cycle 5E, tahapan-tahapan pada siklusnya tidak berakhir pada siklus terakhir. Setelah tahapan elaborasi berakhir, keterlibatan siklus belajar berikutnya dimulai, tehap evaluasi bukan merupakan tahapan yang terakhir melainkan evaluasi terjadi di semua empat bagian siklus pembelajaran. Kelima tahapan (fase) tersebut, jika digambarkan dalam bentuk silkus, maka seperti pada gambar 1 berikut ini: 


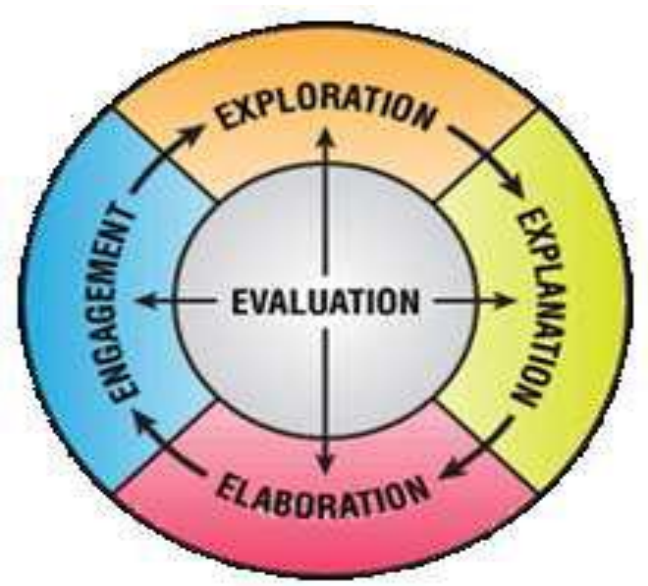

\section{Gambar 1. Tahapan Model Pembelajaran Learning Cycle 5E}

Adapun sintaks model pembelajaran siklus belajar 5E yang dikutip Bybee, dkk (2006), Lorsbach (Yuliati, 2015) disajikan pada Tabel 2 berikut.

Tabel 2. Sintaks Model Pembelajaran Learning Cycle 5E

\begin{tabular}{|c|c|}
\hline Tahapan (Fase) & Kegiatan pembelajaran \\
\hline $\begin{array}{l}\text { Engagement } \\
\text { (keterlibatan) }\end{array}$ & $\begin{array}{l}\text { 1. Guru memusatkan perhatian siswa } \\
\text { 2. Guru membangkitkan minat, motivasi, dan rasa } \\
\text { keingintahuan siswa terkait materi yang diajarkan } \\
\text { 3. Guru memfasilitasi siswa dalam menguji pengetahuan } \\
\text { awal dengan memberikan pertanyaan atau masalah } \\
\text { mengenai materi yang dipelajari }\end{array}$ \\
\hline $\begin{array}{l}\text { Eksploration } \\
\text { (penjelajahan) }\end{array}$ & $\begin{array}{l}\text { 1. Guru membagi LKS, memberikan suatu permasalahan } \\
\text { untuk dicari solusinya oleh siswa. } \\
\text { 2. Siswa membentuk kelompok kecil untuk melakukan } \\
\text { diskusi menyangkut materi yang diberikan guru serta } \\
\text { mencari jawaban untuk permasalahan tersebut, melakukan } \\
\text { praktikum, membuat hipotesis, dan mengumpulkan data } \\
\text { hasil praktikum. } \\
\text { 3. Guru berperan sebagai pembimbing }\end{array}$ \\
\hline $\begin{array}{l}\text { Eksplanation } \\
\text { (menjelaskan) }\end{array}$ & $\begin{array}{l}\text { 1. Siswa melakukan diskusi kelompok untuk menganalisis } \\
\text { data yang dikumpulkan dari kegiatan pada tahapan } \\
\text { sebelumnya } \\
\text { 2. Siswa menjelaskan konsep, informasi, dan pengetahuan } \\
\text { yang diperoleh sebelumnya sesuai dengan apa yang } \\
\text { meraka pelajari dan pahami. } \\
\text { 3. Guru membantu siswa untuk mengingat kembali materi } \\
\text { yng sudah dipelajari ataupun memperbaiki data yang salah } \\
\text { dengan materi yang baru. }\end{array}$ \\
\hline $\begin{array}{l}\text { Elaboration } \\
\text { (elaborasi) }\end{array}$ & $\begin{array}{l}\text { 1. Siswa dapat menerapkan konsep, informasi, pengetahuan, } \\
\text { dan kemampuan mereka yang terampil yang diperoleh dari } \\
\text { fase sebelumnya ke dalam situasi yang baru yang memiliki } \\
\text { penyelesaian yang sama. } \\
\text { 2. Siswa menerapkan pemahaman konsep mereka dengan } \\
\text { melakukan kegiatan tambahan }\end{array}$ \\
\hline $\begin{array}{l}\text { Evaluation } \\
\text { (menilai) }\end{array}$ & $\begin{array}{l}\text { 1. Guru memberikan umpan balik dengan menanyakan } \\
\text { kembali materi, pengetahuan yang telah dipelajari. Hal ini } \\
\text { dilakukan untuk mengetahui tingkat pengetahuan atau } \\
\text { pemahaman siswa terhadap materi yang telah dipelajari. } \\
\text { 2. Guru melakukan penilaian hasil belajar siswa. }\end{array}$ \\
\hline
\end{tabular}


Berdasarkan sintaks model pembelajaran learning cycle $5 E$, pengetahuan yang diberikan guru kepada siswa dalam proses pembelajaran bukan lagi sekedar trasnfer ilmu pengetahuan semata, melainkan proses perolehan konsep yang didasarkan pada keikutsertaan atau keterlibatan siswa secara aktif dalam proses pembelajaran. Model pembelajaran learning cycle $5 E$ ini lebih ditegaskan atau berpusat pada siswa. Qarareh (2012) berpendapat bahwa model learning cycle $5 E$ mampu menciptakan sebuah pembelajaran bermakna yang dapat meningkatkan prestasi belajar siswa, motivasi belajar siswa serta membantu mereka untuk belajar secara aktif. Demikian juga dikatakan Soomro, et al (2010) bahwa model learning cycle $5 E$ ini sangat berpengaruh dalam meningkatkan pemahaman dan prestassi belajar siswa, membantu siswa menikmati sains, mengerti materi, dan mengaplikasikan dalam situasi ilmiah.

\section{METODE}

Jenis penelitian yang digunakan adalah penelitian tindakan kelas (PTK). Penelitian ini berfokus pada upaya guru dalam meningkatkan kemampuan kognitif dan aktivitas belajar siswa melalui model pembelajaran learning cycle $5 E$ pada siswa kelas VIIA di SMP Swasta Kristen Ende. Waktu penelitian dilaksanakan pada bulan Mei 2019. Subjek penelitian ini adalah siswa kelas VIIA di SMP Swasta Kristen Ende yang sebanyak 30 siswa. Penelitian ini menggunakan model penelitian yang dikemukakan oleh Kemmis \& MC Taggart (Endang, 2014: 70). Adapun model penelitian tindakan kelas yang dimaksud menggambarkan adanya empat langkah yaitu:

a. Tahap Perencanaan

Dalam tahap perencanaan perlu mempersiapkan perangkat pembelajaran yakni silabus, Rencana Pelaksanaan Pembelajaran (RPP), Lembar Kerja Siswa (LKS), lembar jawaban, lembar observasi, dan lembar angket serta perlengkapan yang digunakan dalam pembelajaran.

b. Tahap Pelaksanaan

Pada tahap ini meliputi kegiatan belajar mengajar (KBM) dengan menggunakan model pembelajaran learning cycle $5 E$ pada mata pelajaran IPA.

c. Tahap Pengamatan

Pada tahap ini peneliti melakukan pengamatan dengan mencatat semua hal yang diperlukan dan terjadi selama pelaksaanan berlansung. Pengumpulan data dalam pengamatan ini menggunakan data kualitatif dan hasil tes belajar siswa.

d. Tahap Refleksi

Merefleksi siklus 1 didasarkan pada pengamatan aktivitas belajar dan tes kemampuan kognitif siswa kelas VIIA di SMP Swasta Kristen Ende tahun pelajaran 2018/2019. Jika tidak berhasil, maka dilanjutkan dengan siklus II.

Teknik analisis data yang dilakukan dengan menggunakan metode statistik. Rumus statistik digunakan untuk menilai kemampuan kognitif siswa melalui teknik tes dengan mencari nilai rata-rata dan persentase ketuntasan hasil belajar siswa.

1. Rumus untuk mencari nilai rata-rata (Sugiyono, 2013: 49)

$$
M e=\frac{\sum X_{i}}{n}
$$


2. Rumus untuk mencari persentase ketuntasan hasil belajar siswa.

$$
N=\frac{\text { jumlah siswa yang tuntas }}{\text { jumlah siswa }} \times 100 \%
$$

\begin{tabular}{|l|c|l|}
\hline No & Nilai & \multicolumn{1}{|c|}{ Kategori } \\
\hline 1. & $90-100$ & Sangat baik \\
\hline 2. & $80-89$ & Baik \\
\hline 3. & $70-79$ & Cukup \\
\hline 4. & $<70$ & Kurang \\
\hline
\end{tabular}

3. Untuk menilai aktivitas belajar siswa melalui teknik observasi dan angket dengan menggunakan rumus sebagai berikut ini.

$N=\frac{\text { jumlah skor yang diperoleh }}{\text { jumlah skormaksimal }} \times 100 \%$

\section{HASIL DAN PEMBAHASAN}

Penerapan model pembelajaran learning cycle $5 E$ mampu meningkatkan kemampuan kognitif dan aktivitas belajar siswa kelas VIIA di SMP Swasta Kristen Ende tahun pelajaran 2018/2019. Dalam pembelajaran ini siswa dituntut untuk belajar mandiri dan kelompok, dengan kemampuan yang dimiliki siswa bisa menganalisah bahasa buku menggunakan bahasanya sendiri.

\section{Peningkatan Kemampuan Kognitif Siswa}

Hasil kemampuan kognitif siswa pada siklus I dan siklus II terdapat pada tabel 3. Data pada tabel menunjukkan terjadi peningkatan hasil kemampuan kognitif siswa yang memenuhi kategori tuntas dan besarnya presentasi dari setiap siklus. Dari data pada tabel 3 kemudian disederhanakan dengan membuat model grafik batang seperti ditujukkan pada gambar 2 .

Tabel 3. Peningkatan Hasil Test Uji Kemampuan Kognitif Siswa

\begin{tabular}{|l|c|c|c|c|}
\hline \multirow{2}{*}{$\begin{array}{c}\text { Kategori } \\
\text { Kemampuan } \\
\text { Kognitif Siswa }\end{array}$} & \multicolumn{2}{|c|}{ Siklus I } & \multicolumn{2}{c|}{ Siklus II } \\
\cline { 2 - 5 } & Jumlah Siswa & Persentase (\%) & Jumlah Siswa & Persentase (\%) \\
\hline Tuntas & 11 & 37 & 30 & 100 \\
\hline Tidak Tuntas & 19 & 63 & 0 & 0 \\
\hline Total & 30 & 100 & 30 & 100 \\
\hline
\end{tabular}

Berdasarkan tabel di atas dapat dijelaskan bahwa hasil kemampuan kognitif siswa pada siklus I, ada 11 siswa (37\%) yang sudah tuntas dan 19 siswa (63\%) yang belum tuntas. Pada siklus II terjadi peningkatan hasil kemampuan kognitif siswa. Peningkatan hasil kemampuan kognitif siswa dari siklus I sebanyak 19 siswa (63\%). Hal ini menandakan bahwa pada siklus II sudah memenuhi kriteria keberhasilan tindakan 
yaitu $70 \%$. Dari penjelasan di atas dapat diambil kesimpulan bahwa model pembelajaran learning cycle $5 E$ dapat meningkatkan kemampuan kognitif siswa.

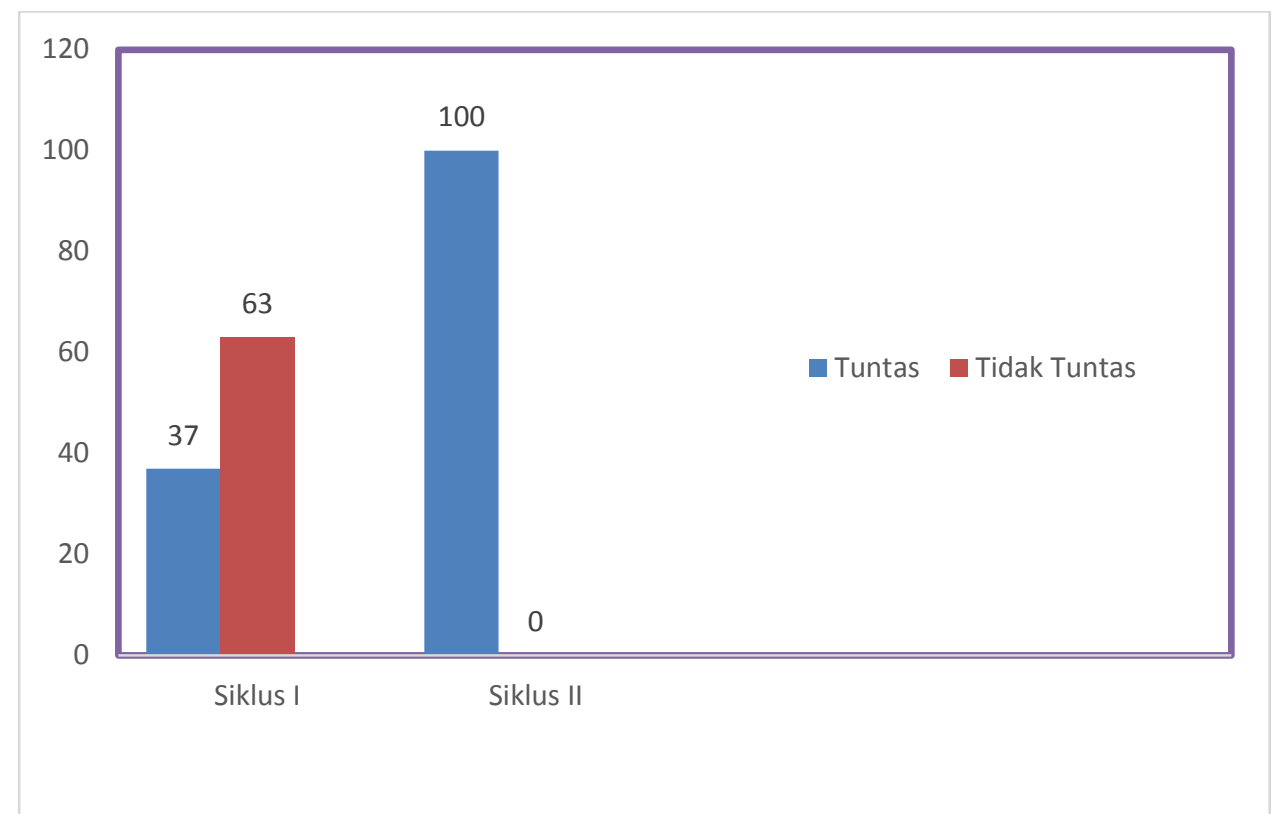

Gambar 2. Perbandinagn Persentase Peningkatan Hasil Test Uji Kemampuan Kognitif Siklus I dan Siklus II

Adanya peningkatan kemampuan kognitif siswa yang ditunjukkan pada gambar 2, didukung dengan penelitian yang dilakukan oleh Hesty Sapitry, dkk (2013), dimana hasil penelitian menunjukkan bahwa model learning cycle $5 E$ efektif untuk meningkatkan kemampuan kognitif siswa aspek pengetahuan ditinjau dari hasil belajar dengan persentase siswa yang mendapatkan hasil > 60 sebesar $91,10 \%$ dengan nilai ratarata 79,68 .

\section{Pencapian Aktivitas Belajar Siswa}

Penerapan model pembelajaran learning cycle $5 E$ dapat meningkatkan aktivitas belajar siswa dalam kegiatan pembelajaran. Peningkatan aktivitas belajar siswa secara umum dapat meningkat hingga mencapai kriteria keberhasilan tindakan $(70 \%$ dari jumlah siswa yang memperoleh nilai $\geq 70$ ) dengan membutuhkan dua siklus. Untuk mengetahui kriteria keberhasilan tindakan tersebut, data dikumpulkan dengan menggunakan observasi dan angket untuk aktivitas belajar siswa. Data aktivitas belajar siswa dapat dilihat pada tabel 4 di bawah. 
Tabel 4. Data Hasil Aktivitas Belajar Siswa Siklus I dan II

\begin{tabular}{|c|c|c|c|c|c|c|c|c|}
\hline \multirow{2}{*}{$\begin{array}{c}\text { Kategori } \\
\text { Aktivitas } \\
\text { Belajar Siswa }\end{array}$} & \multicolumn{4}{|c|}{ Observasi } & \multicolumn{4}{c|}{ Angket } \\
\cline { 2 - 9 } & \multicolumn{2}{|c|}{ Siklus I } & \multicolumn{2}{c|}{ Siklus II } & \multicolumn{2}{c|}{ Siklus I } & \multicolumn{2}{c|}{ Siklus II } \\
\cline { 2 - 9 } & $\begin{array}{c}\text { Jlh } \\
\text { Siswa }\end{array}$ & $\%$ & Siswa & $\%$ & $\begin{array}{c}\text { Jlh } \\
\text { Siswa }\end{array}$ & $\%$ & $\begin{array}{c}\text { Jlh } \\
\text { Siswa }\end{array}$ & $\%$ \\
\hline T & 13 & 43 & 30 & 100 & 12 & 40 & 30 & 100 \\
\hline TT & 17 & 57 & 0 & 0 & 18 & 60 & 0 & 0 \\
\hline Total & 30 & 100 & 30 & 100 & 30 & 100 & 30 & 100 \\
\hline
\end{tabular}

Ket: T (Tuntas), TT (Tidak Tuntas)

Berdasarkan data aktivitas belajar siswa pada tabel di atas dapat dijelaskan bahwa hasil observasi aktivitas belajar siswa pada siklus I, ada 13 siswa (43\%) yang sudah tuntas (T) dan 17 siswa (57\%) yang belum tuntas (TT). Untuk mencapai kriteria keberhasilan tindakan yaitu $70 \%$ dibutuhkan $27 \%$ atau 8 siswa lagi untuk masuk kategori tuntas. Pada siklus II terjadi peningkatan jumlah siswa yang masuk dalam kategori tuntas. Peningkatan observasi aktivitas belajar siswa dari siklus I ke siklus II sebanyak 17 siswa (57\%). Hal ini menandakan bahwa pada siklus II sudah memenuhi kriteria/kategori keberhasilan tindakan.

Pada siklus I hasil angket aktivitas belajar siswa, ada 12 siswa (40\%) yang sudah tuntas dan 18 siswa $(60 \%)$ yang belum tuntas. Untuk mencapai kriteria keberhasilan tindakan yaitu $70 \%$ dibutuhkan $30 \%$ atau 9 siswa untuk mencapai kategori tuntas.Pada siklus II juga terjadi peningkatan hasil angket aktivitas belajar siswa yang masuk kategori tuntas. Peningkatan aktivitas belajar siswa dari siklus I ke siklus II sebanyak 18 siswa (60\%). Hal ini juga menandakan bahwa pada siklus II sudah memenuhi kriteria/kategori keberhasilan tindakan.

Dari data peningkatan hasil observasi dan angket aktivitas belajar siswa pada siklus I dan siklus II, dapat disimpulkan bahwa model pembelajaran learning cycle $5 E$ dapat meningkatkan aktivitas belajar siswa. 


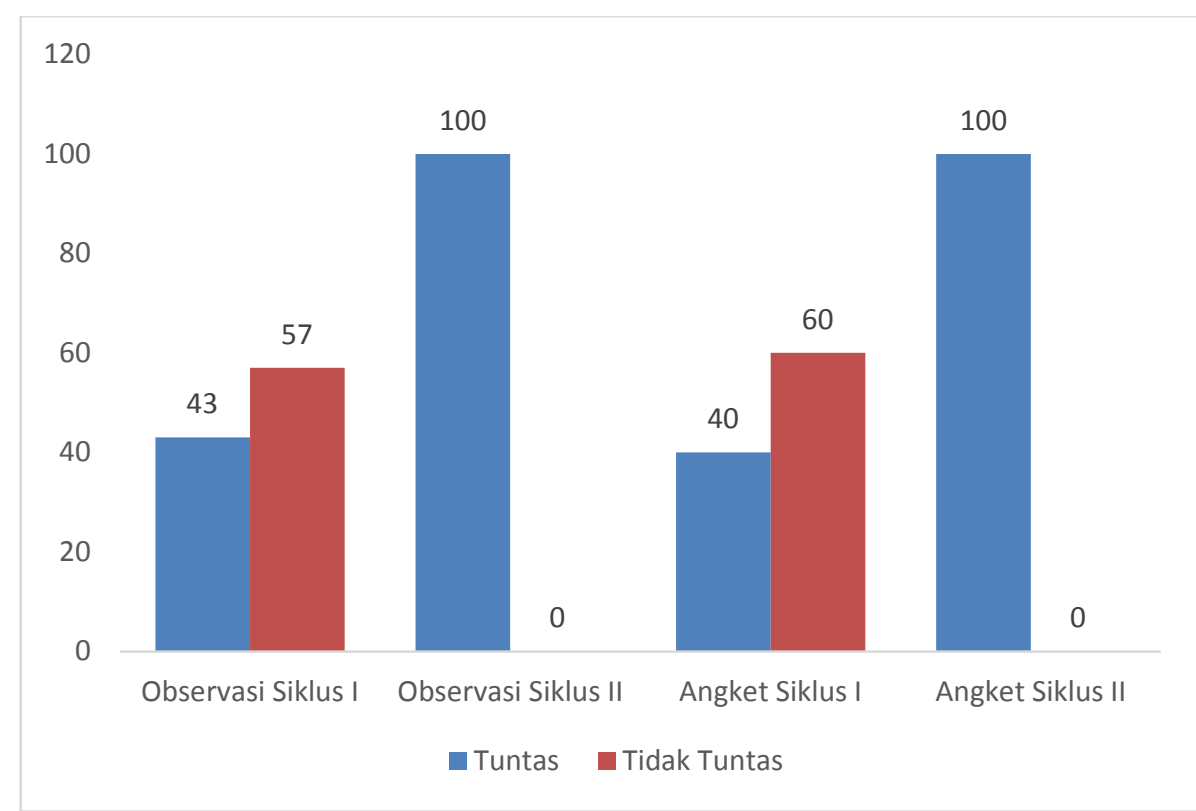

Gambar 3. Perbandingan Persentase Peningkatan Hasil Observasi dan Angket Aktivitas Belajar Siswa Siklus I dan Siklus II

Hal ini didukung dengan penelitian oleh Lestari, dkk (2015), dengan judul "Penerapan Model Pembelajaran Learning Cycle 5E Dengan Metode Pemberian Tugas Dan Prestasi Untuk Meningkatkan Aktivitas dan Hasil Belajar Matematika Pada Pokok Bahasan Aritmetika Sosial Siswa Kelas VIIA Semester Genap SMP Negeri 10 Jember Tahun Pelajaran 2013/2014". Hasil penelitian menunjukkan bahwa aktivitas belajar siswa mengalami peningkatan dari siklus I ke siklus II.

Tabel 5. Analisis Hasil Aktivitas Belajar Siswa Untuk Setiap Indikator

\begin{tabular}{|l|c|c|}
\hline \multicolumn{1}{|c|}{ Aktivitas Belajar Siswa } & Siklus I & Siklus II \\
\hline Mengamati eksperimen & $73 \%$ & $82,22 \%$ \\
\hline Mengajukan pertanyaan & $64,06 \%$ & $76,39 \%$ \\
\hline $\begin{array}{l}\text { Mengemukakan pendapat/menyubang ide } \\
\text { dalam kerja kelompok }\end{array}$ & $69,72 \%$ & $76,53 \%$ \\
\hline Mendengarkan penyajian bahan & $71,39 \%$ & $75,69 \%$ \\
\hline Mendengarkan diskusi kelompok & $71,32 \%$ & $82,78 \%$ \\
\hline Membuat rangkuman/catatan & $62,08 \%$ & $73,33 \%$ \\
\hline Membuat keputusan/kesimpulan masalah penggunaan & $65,97 \%$ & $77,08 \%$ \\
\hline $\begin{array}{l}\text { Memecahkan kn matematika dalam kehidupan sehari-hari } \\
\text { matem }\end{array}$ & $81,94 \%$ \\
\hline
\end{tabular}




\section{PENUTUP}

Berdasarkan hasil penelitian dan pemabahasan dapat disimpulkan:

1. Model pembelajaran learning cycle $5 E$ dapat meningkatkan kemampuan kognitif siswa kelas VIIA di SMP Swasta Kristen Ende tahun pelajaran 2018/2019. Hasil kemampuan kognitif yang sudah tuntas pada siklus I sebanyak 11 siswa (37\%) dan siklus II sebesar 30 siswa (100\%). Peningkatan hasil kemampuan kognitif siswa yang tuntas dari siklus I ke siklus II sebesar 19 siswa $(63 \%)$.

2. Model pembelajaran learning cycle $5 E$ dapat meningkatkan aktivitas belajar siswa kelas VIIA di SMP Swasta Kristen Ende tahun pelajaran 2018/2019. Peningkatan hasil aktivitas belajar siswa diperoleh dari data yang dikumpulkan peneliti melalui observasi dan angket. Hasil observasi aktivitas belajar siswa pada siklus I yang tuntas sebanyak 13 siswa (43\%) dan pada siklus II sebanyak 30 siswa (100\%). Peningkatan hasil observasi aktivitas belajar siswa yang tuntas dari siklus I ke siklus II sebayak 17 siswa (57\%). Sedangakn hasil angket aktivitas belajar siswa pada siklus I yang tuntas sebanyak 12 siswa (40\%) dan pada siklus II sebanyak 30 siswa (100\%). Peningakatan hasil angket aktivitas belajar siswa yang tuntas dari siklus I ke siklus II sebanyak 18 siswa (60\%).

\section{UCAPAN TERIMA KASIH}

Terimakasih penulis ucapkan kepada Kepala SMPS Kristen yang telah memberikan kesempatan bagi penulis untuk melaksanakan penelitian, dan juga Kepala LPPM Universitas Flores yang telah banyak membantu demi kelancaran pelaksanaan penelitian.

\section{DAFTAR PUSTAKA}

Handayani, G.A., et al. (2014). Pengaruh Model Siklus Belajar 5E Berbasis Pemecahan Masalah Terhadap Kemampuan Pemecahan Masalah Matematika Ditinjau Dari Pengetahuan Awal Siswa. e-Jurnal Program Pascasarjana Universitas Pendidikan Ganesha. 3.

Endang, M. (2014). Metode Penelitian Terapan Bidang Pendidikan. Bandung: Alfabeta

Hesty Sapitry, et al. (2013). Efektivitas Model Learning Cycle 5e Dalam Pembelajaran Sejarah Untuk Meningkatkan Kemampuan Kognitif. FKIP Unila Bandar Lampung 35145 .

Lestari, E.C.,et al. (2015). Penerapan Model Pembelajaran Learning Cycle 5E Dengan Metode Pemberian Tugas Dan Resitasi Untuk Meningkatkan Aktivitas Dan Hasil Belajar Matematika Pada Pokok Bahasan Aritmetika Sosial Siswa Kelas VII A Semester Genap SMP Negeri 10 Jember Tahun Pelajaran 2013/2014. Jurnal Kadikma. 6(2): 83-94.

Mustiqon. (2012). Pengembangan Media \& Sumber Pembelajaran. Jakarta: Prestasi Pustakaraya.

Sugiantara, et al. (2012). Pengaruh Model Pembelajaran Learning Cycle 5E Terhadap Hasil Belajar IPA Siswa Kelas V Di Gugus VII Kecamatan Buleleng.FIP. Singaraja Indonesia.

Sugiyono. (2013). Statistika Untuk Penelitian. Bandung: Alfabeta. 